\title{
Ekstraksi Satu Tahap Pada Makroalga Basah dan Kering Sebagai Bahan Baku Biodiesel
}

\author{
Vera Viena ${ }^{1, *}$, Bahagia ${ }^{2}$, Restu Ginanjar Wibowo ${ }^{3}$ \\ ${ }^{1,2,3}$ Program Studi Teknik Lingkungan, Universitas Serambi Mekkah \\ Jl. Tgk Imum Lueng Bata, Batoh, Kota Banda Aceh, Indonesia 23245 \\ *Koresponden email: veraviena@serambimekkah.ac.id
}

Diterima: 21 Maret 2019

Disetujui: 29 Maret 2019

\begin{abstract}
Macroalgae has potency to expand as one of alternatives for feedstock of biodiesel. The research has aim to extract the wet and dried macroalgae using one step method. Extraction was done by comparing the conventional methods of Bligh-Dyer, sochletation to one steps method. One step extraction method resulting a higher total lipid in wet biomass $(49.67 \% \mathrm{~W} . \mathrm{W})$ than dried biomass $(45.67 \% \mathrm{D} . \mathrm{W})$, while conventional methods of sokhletation and Bligh-Dyer resulting total lipids of $37.67 \%$ and $39.33 \%$ Wet Weight (W.W); and $45.67 \%$ and $40.67 \%$ Dried weight (D.W), respectively. Identification of oil/lipid content of the macroalgae extract using Gas chromatography showed 3 highest peak e.i which contained 9-Octadecanoic acid (Z), methyl ester (Asam oleat) of $52.44 \%$ area, 9-12,Octadecadienic, (Z.Z) (Asam linoleat) of $22.12 \%$ area and Octadecanoic acid, (CAS) methyl stearate, of $20.36 \%$ area. Those three main fatty acid compounds were commonly found in algae oil and had great potention to be used as one of alternative feedstock for biodiesel.

Keywords: Macroalgae, extraction, one step method, fatty acid of algae.
\end{abstract}

\begin{abstract}
Abstrak
Makroalga sangat berpotensi dikembangkan di Indonesia sebagai alternatif bahan baku biodiesel masa depan. Penelitian ini bertujuan untuk mengekstraksi makroalga basah dan kering dengan metode satu tahap sebagai bahan baku biodiesel. Ekstraksi dilakukan dengan membandingkan proses ektraksi konvensional sokhletasi, Bligh-Dyer dan metode satu tahap. Metode ekstraksi satu tahap menghasilkan total lipida lebih tinggi dalam bentuk biomassa basah (49,67\% BB) dibandingkan biomassa kering (45,67\%). Sedangkan Metode konvensional sokletasi dan Bligh Dyer menghasilkan kandungan total lipida sebesar $37.67 \%$ dan $39.33 \%$ Berat kering (BB) dan sebesar 45,67 dan 40,67 \% (BK). Hasil identifikasi senyawa minyak/lemak pada ekstrak makroalga menggunakan alat Gas Chromatography menunjukkan hasil 3 puncak tertinggi, yaitu mengandung senyawa 9-Octadecanoic acid (Z), methyl ester (Asam oleat) sebesar 52,44 \% area, 9-12,Octadecadienic, (Z.Z) (Asam linoleat) sebesar 22,12 \% area dan Octadecanoic acid, (CAS) methyl stearate, sebesar 20,36 \% area. Ketiga asam lemak ini merupakan komponen utama yang umumnya terdapat didalam minyak nabati alga dan berpotensi besar untuk dimanfaatkan sebagai bahan baku biodiesel.
\end{abstract}

Kata kunci: makroalga, ekstraksi, metode satu tahap, asam lemak alga.

\section{Pendahuluan}

Dewasa ini kebutuhan akan minyak bumi sebagai sumber bahan bakar semakin meningkat. Hal ini dapat dilihat dari data BPH Migas tentang jumlah konsumsi Bahan Bakar Minyak (BBM) nasional pada tahun 2014 lalu untuk Jenis BBM Tertentu (JBT) sudah mencapai 47.789.625,18 L per tahun. Terjadi peningkatan jika dibandingkan pada tahun 2009, kebutuhan akan Jenis BBM Tertentu (JBT) di Indonesia berkisar 37.836.379,19 L per tahun nya (www.bphmigas.go.id). Akan tetapi ketergantungan akan sumber energi dari minyak bumi ini tidak diimbangi dengan kepedulian bahwa sumber energi dari fosil ini terbatas jumlahnya dan suatu saat dapat habis. Selain itu, minyak bumi merupakan salah satu sumber energi yang tidak dapat diperbarui karena membutuhkan waktu yang sangat lama untuk beregenerasi.

Salah satu contoh dari vegetable oil adalah minyak dari alga. Alga merupakan salah satu sumber biodiesel yang paling baik. Untuk luas tempat penumbuhan yang sama, alga dapat menghasilkan minyak (yang kemudian dapat diolah menjadi biodiesel) 250 kali lebih banyak daripada minyak yang dihasilkan oleh tanaman hasil pertanian (Susanto, 2012). Ekstraksi 
minyak dari alga juga sangat sederhana. Salah satu alga yang dapat digunakan untuk biodiesel adalah Makroalga.

Makroalga atau rumput laut adalah ganggang multiseluler yang hidup di perairan laut yang tergolong dalam divisi Thallophyta. Makroalga belum terdeferensiasi menjadi akar, batang, dan daun seperti lazimnya tanaman tingkat tinggi (Dawes, 1998). Makroalga banyak mengandung senyawa organik yang sangat penting dalam dunia obat-obatan maupun dunia mikrobia (Winarno, 1990).

Makroalga dapat ditemukan di habitat yang memiliki salinitas, temperatur, intensitas cahaya dan nutrisi yang cukup. Selain itu sebaran makroalga dapat ditemukan di seluruh perairan laut yang memiliki terumbu karang. Kadar salinitas yang baik untuk makroalga pada umumnya yaitu 30-35 permil sedangkan untuk temperatur $25-29{ }^{\circ} \mathrm{C}$, kedalaman minimal sekitar $50 \mathrm{~cm}$ dan mendapatkan arus yang cukup yaitu sekitar 0,2-0,4 m/detik (Nugroho dan Agung, 2010).

Makroalga terkenal sebagai bahan baku untuk makanan, obat-obatan dan untuk kosmetik, selain itu berpotensi sebagai penghasil biodiesel karena makroalga dapat memproduksi biomasssa yang cukup signifikan yaitu 1-2 ton selain itu makroalga mudah dibiakkan di tempat yang tidak banyak membutuhkan pupuk, proses pemanenan makroalga lebih mudah dibanding dengan mikroalga. Proses pemanenan mikroalga dengan menggunakan teknik flokulasi, sentrifugasi dan filtrasi sedangkan pemanenan makroalga hanya butuh dipetik saja tidak serumit pemanenan untuk mikroalga (Ariyanti, 2012). Karakteristik ini membuat makroalga menjadi sumber energi yang cocok di masa mendatang (Narsi, 2007).

Untuk mendapatkan minyak dari proses ekstraksi makroalga beberapa metode telah digunakan, dan diantara metode konvensional yang sering digunakan dalam proses ekstraksi untuk mikroalga adalah metode Folch, Bligh Dyer dan Soxhletasi. Berdasarkan Axelsson (2014), perbedaan utama antara protokol Folch et al. (1957) dan Bligh dan Dyer (1959) adalah volume sistem pelarut terhadap jumlah sampel, rasio antara pelarut dalam sistem, dan ada atau tidaknya $\mathrm{NaCl}$ dalam fraksi air yang ditambahkan. Metode Bligh dan Dyer (1959) menggunakan ekstraksi dengan penambahan kloroform-metanol 1:2 dan 1:1 (v/v), jumlah volume akhir setara dengan empat kali jumlah sampel. Penggunaan kloroform yang bersifat beracun telah banyak dikembangkan untuk dapat digantikan dengan sistem pelarut lain sebagai alternatif dari metode konvensional, tetapi ini umumnya kurang efisien untuk ekstraksi total lipid basah dan sensitif terhadap kadar air dalam sampel (Fishwick dan Wright, 1977). Metode konvensional berbasis kloroform dianggap unggul untuk ekstraksi total lipid, tetapi mereka juga memiliki kelemahan karena membutuhkan tenaga dan memakan waktu, sehingga membatasi jumlah perlakuan sampel. Namun sampai saat ini belum ada penelitian tentang ekstraksi lipida makroalga menggunakan metode konvensional dan metode satu tahap, karena umumnya metode tersebut hanya dipakai pada ekstraksi lipida mikroalga. Untuk itu, peneliti mencoba membandingan penggunaan metode ekstraksi lipida mikroalga terhadap makroalga hijau lokal perairan Aceh.

Penelitian ini bertujuan untuk membandingkan aplikasi proses ekstraksi konvensional Bligh-Dyer dan Sokhletasi dengan metode satu tahap (one step) pada makroalga basah dan kering sebagai alternatif bahan baku biodiesel. Metode Satu Tahap adalah metode lanjutan dari metode Bligh Dyer dengan penambahan pelarut kloroform, metanol dan katalis sebesar $4 \%$ ke dalam labu operasi untuk memperoleh ekstrak lipida secara total. Diharapkan metode satu tahap ini dapat diterapkan untuk ekstraksi makroalga dalam bentuk basah maupun kering, sehingga dapat dijadikan sebagai dasar untuk alternatif pengolahan bahan baku biodiesel.

\section{Metode Penelitian}

1. Biomassa dan Preparasi Sampel

Makroalga lokal diperoleh dari perairan Banda Aceh dibudidayakan dalam fotobioreaktor denga aerasi dalam kondisi pencahayaan 24 jam (suhu $28-30{ }^{\circ} \mathrm{C}$ dan kultivasi di Laboratorium Lingkungan, Universitas Serambi Mekkah). Dengan media perikanan dan aerasi $10 \mathrm{~L} / \mathrm{mnt}$, mikroalga mencapai akhir pertumbuhan fase log dan dipanen pada hari ke 6. Untuk ektraksi lipida, Makroalga diperoleh dengan sentrifugasi suspensi (pada $4.500 \mathrm{rpm}$ selama 10 menit) diikuti oleh liofilisasi. Sedangkan untuk ekstraksi makroalga basah diperoleh dengan filtrasi setelah 6 hari kultivasi dan diperas untuk mengurangi kandungan air.

Untuk studi transesterifikasi, sel liophilized dari makroalga digunakan. Semua sampel disimpan pada suhu $4{ }^{\circ} \mathrm{C}$ sampai digunakan.

\section{Metode dan Ekstraksi Lipida}

Berbagai metode ekstraksi seperti ekstraksi Soxhlet dan Bligh Dyer diuji cobakan untuk melihat efeknya pada hasil dan komposisi lipida yang diekstraksi. Prosedur dan kondisi yang diperiksa untuk setiap metode disediakan sebagai 
berikut. Untuk semua metode, setiap ekstrak disaring menggunakan kertas saring untuk menghilangkan residu biomassa. Larutan yang disaring kemudian diuapkan, dan lemak kasar yang tersisa diukur secara gravimetri.

\section{a. Ekstraksi Soxhlet}

Ekstraksi soxhlet diasumsikan sebagai metode yang dapat sepenuhnya mengekstraksi semua lipida yang disajikan dalam mikroalga, menghasilkan pemulihan 100\%. Dengan demikian, jumlah lipida yang diekstraksi dari metode lain dilaporkan berdasarkan pada yang diekstraksi dengan metode ini. Di sini, 3 gram ganggang diekstraksi selama 4 jam dengan $180 \mathrm{ml}$ pelarut dalam peralatan Soxhlet. Efek dari dua pelarut yang berbeda dipelajari, yaitu hexane dan campuran khloroform dan methanol pada 2:1 (v/v). Rasio ini dikembangkan oleh Folch et al., (1957) berdasarkan pada prinsip bahwa pelarut ekstraksi lipida harus cukup polar untuk menghilangkan lipida dari hubungannya dengan membran sel dan konstituen jaringan tetapi juga tidak begitu polar sehingga pelarut tidak siap. larutkan semua triasilgliserol dan lipida nonpolar lainnya.

\section{b. Bligh Dyer}

Sel alga basah yang dipanen dikeringkan dan dihancurkan dengan mortar dan dipindahkan kedalam corong pemisah. Lipid diekstraksi dengan larutan kloroform metanol $(2: 1, \mathrm{v} / \mathrm{v})$ dan terpisah menjadi lapisan cairan kloroform dan metanol dengan penambahan metanol dan air untuk menghasilkan rasio pelarut akhir dari kloroform : metanol : air sebesar 1:1:0.9. Lapisan kloroform dicuci dengan $20 \mathrm{ml}$ larutan $\mathrm{NaCl} 5 \%$, dan diuapkan sampai kering, total lipid ditentukan secara gravimetri.

\section{c. Metode Satu Tahap}

Metode Satu-Tahap dilakukan dengan 3 gram ganggang kering dan/atau (ganggang basah) dimasukkan ke dalam labu, di mana katalis, alkohol dan pelarut ditambahkan untuk memungkinkan ekstraksi lipida dan transesterifikasi berlangsung secara bersamaan. Untuk membandingkankinerjanya dengan produksi biodiesel Dua-Tahap konvensional, kondisi yang dipilih digunakan untuk kedua metode, yaitu transesterifikasi pada 4\% katalis, rasio alkohol terhadap biomassa 16:1 (v/w) dan waktu reaksi 2 jam. Setelah reaksi biomassa disaring dengan kertas Whatman (Prommuak et al, 2012).
3. Analisis Ekstrak Lipida dari Berbagai Pelarut Untuk memilih pelarut yang cocok untuk ekstraksi lipida mikroalga, lipida mentah yang diekstraksi oleh heksana dan $\mathrm{C} / \mathrm{M}$ dikonversi menjadi biodiesel. Jumlah biodiesel dianalisis oleh GC-MS mengikuti metode standar AOAC (2005). Persamaan yang digunakan untuk menghitung berat ekstrak lipida adalah sebagai berikut:

$$
\begin{aligned}
& \text { Yield }=\frac{\text { berat } \min y a k}{\text { berat biomassa } \text { kering }} \times 100 \% \\
& \text { Yield }=\frac{\text { berat } \text { min } y a k}{\text { beratbiomassabasah }} \times 100 \%
\end{aligned}
$$

4. Transesterifikasi Lipida Mikroalga

a. Produksi Biodiesel Konvensional Dua Tahap Dalam produksi Dua-Tahap, transesterifikasi dilakukan pada lipida yang sebelumnya diekstraksi dari 3 gram ganggang kering dengan rasio kloroform/methanol (C/M) menggunakan peralatan Soxhlet, mengikuti metode yang dijelaskan sebelumnya. Ke dalam sebuah bejana yang dilengkapi dengan kondensor, minyak yang diekstraksi diisi bersama dengan larutan alkosida dari katalis alkali $\mathrm{KOH}$ (Merck, Jerman) (2-8\% dari berat ganggang) dan metanol pada berbagai metanol menjadi alga biomassa $(\mathrm{v} / \mathrm{w})$ rasio (8:1, 12:1 dan 16:1). Campuran dipanaskan sampai suhu terkontrol $60{ }^{\circ} \mathrm{C}$. Reaksi dibiarkan berlangsung selama 1, 2, 3 atau 4 jam. Labu didinginkan hingga suhu kamar untuk menghentikan reaksi (Prommuak et al, 2012). Pemisahan fase selanjutnya dilakukan mengikuti metode Folch et al. (1957). Di sini, kloroform dan air ditambahkan ke dalam campuran dengan perbandingan campuran: kloroform : air 10:10:9. Setelah dikocok dengan kuat, campuran disentrifugasi pada $2000 \mathrm{rpm}$ selama 10 menit, menghasilkan pemisahan menjadi dua fase. Metanol, gliserol produk samping dan polar lainnya pengotor yang dilarutkan dalam air membentuk fase atas sementara ester metil asam lemak (FAME), asam lemak bebas (FFA), lipid dan senyawa non-polar lainnya terlarut dengan baik dalam fase dasar kloroform, yang dikumpulkan untuk analisis GC lebih lanjut.

b. Produksi Biodiesel Satu Tahap

Metode Satu-Tahap dilakukan dengan 3 gram ganggang kering dan/atau ganggang 
Tabel 1. Hasil ektraksi total lipida makroalga

\begin{tabular}{llcc}
\hline No & Metode ekstraksi & $\begin{array}{c}\text { Makroalga } \\
\text { Basah (\% BB) }\end{array}$ & $\begin{array}{c}\text { Makroalga kering } \\
\text { (\% BK) }\end{array}$ \\
\hline 1 & Sokletasi & 37.67 & 45.67 \\
2 & Bligh - Dyer & 39.33 & 40.67 \\
3 & Satu Tahap & 49.67 & 45.67 \\
\hline
\end{tabular}

Catatan: $\mathrm{BB}=$ Berat Basah; dan BK $=$ Berat Kering

basah dimasukkan ke dalam labu, di mana katalis, alkohol dan pelarut ditambahkan untuk memungkinkan ekstraksi lipida dan transesterifikasi berlangsung secara bersamaan. Untuk membandingkan kinerjanya dengan produksi biodiesel Dua-Tahap konvensional, kondisi yang dipilih digunakan untuk kedua metode, yaitu transesterifikasi pada 4\% katalis, rasio alkohol terhadap biomassa 16:1 (v/w) dan waktu reaksi 2 jam. Setelah reaksi, biomassa disaring oleh kertas Whatman No. 5. Pemisahan fase dilakukan dan produk biodiesel dikumpulkan mengikuti metode yang dijelaskan sebelumnya.

\section{Analisis GC Biodiesel}

Produk yang diperoleh dari percobaan Transesterifikasi Lipida Mikroalga dianalisis untuk jumlah FAME menggunakan Kromatografi Gas (GC), Shimadzu GC-14B, dilengkapi dengan detektor ionisasi nyala (FID) di mana 0,1 mikroliter sampel diinjeksikan ke dalam kolom. Pemisahan sampel produk dicapai oleh kolom kapiler, $25 \mathrm{~m}$ (panjang), $0.32 \mathrm{~mm}, 0.3$ $\mu \mathrm{m}$ (ketebalan film). Suhu injektor dan detektor masing masing diatur pada $270{ }^{\circ} \mathrm{C}$ dan $300{ }^{\circ} \mathrm{C}$. Program suhu elusi memiliki suhu awal 100 ${ }^{\circ} \mathrm{C}$ tahan selama 5 menit sebelum melandai secara linear dengan laju $10{ }^{\circ} \mathrm{C} /$ menit hingga suhu akhir $250{ }^{\circ} \mathrm{C}$. Temperatur akhir kemudian ditahan selama 20 menit, sehingga total jangka waktu 40 menit. Hasil analisis sampel dihitung menggunakan metil heptadekanoat sebagai standar internal.

\section{Hasil Dan Pembahasan}

\subsection{Hasil ekstraksi lipida makroalga}

Ekstraksi lipid adalah salah satu proses yang paling penting dan terbatas untuk produksi biofuel berbasis mikroalga dalam skala besar. Metode konvensional untuk ekstraksi lipid umumnya melibatkan pengeringan sebelum mengekstraksi lipid karena sisa air dalam biomassa mikroalga basah dapat menghambat perpindahan massa lipida dari sel dan akibatnya menyebabkan penurunan efisiensi ekstraksi lipid (Yang et al, 2014). Penelitian ini mencoba membandingkan metode ekstraksi lipida untuk mikroalga dengan penerapan pada makroalga yang banyak tersebar di perairan Indonesia. Penggunaan metode konvensional Folch, Bligh - Dyer dan Sokhletasi adalah sudah umum dalam ektraksi mikroalga, tetapi pada penelitian ini kami mencoba mengaplikasikan metode tersebut untuk ekstraksi makroalga dari ganggang hijau lokal Aceh dengan harapan kandungan total lipida memiliki karakteristik hampir sama dengan kandungan lipida mikroalga.

Pada Tabel 1 ditabulasikan hasil perbandingan ektraksi total lipida menggunakan metode konvensional Sokletasi dan Bligh-Dyer dan satu tahapan. Hasil ektraksi konvensional menunjukkan kandungan total lipida makroalga basah dan kering sedikit berbeda, dimana untuk proses sokletasi total lipida sebesar $37.67 \%$ B.B dan 45.67 B.K. Untuk metode Bligh - Dyer lipida diperoleh 39.33 \% B.B dan 40.67 \% B.K. Perbandingan dengan metode satu tahap menunjukkan kenaikan kandungan total lipida yang sedikit lebih signifikan (45.67\% B.K dan $49.67 \%$ B.B) dibandingan metode konvensional, dimana setengah dari berat sampel telah dapat diekstrak total lipidanya.

Tabel 2. Profil Asam Lemak Makroalga Hasil Ekstraksi Satu-Tahap

\begin{tabular}{lccc}
\hline \multicolumn{1}{c}{ Asam Lemak } & $\begin{array}{c}\text { Berat Molekul } \\
\text { (g/mol) } \\
\text { (a) }\end{array}$ & $\begin{array}{c}\text { Distribusi dalam } \\
\text { sampel (\%) } \\
\text { (b) }\end{array}$ & (a x b) / 100 \\
\hline Methyl Linoleat (As.Linoleat) & 280.452 & 22.12 & 62.04 \\
Methyl Oleat (As.Oleat) & 282.468 & 52.44 & 148.12 \\
Methyl Stearate (As.Stearat) & 284.484 & 20.36 & 57.92 \\
14-Methyl-8-hexadecyn-1-ol (Zat lain) & 252.442 & 1.87 & 4.72 \\
Ethyl Oleate & 310.522 & 3.21 & 9.97 \\
\hline Rata-rata berat molekul asam-asam lemak & & & 282.77 \\
\hline
\end{tabular}


Hal ini dipengaruhi oleh penggunaan pelarut dan juga semua pelarut, serta katalis $\mathrm{KOH}$ kedalam labu operasi sehingga memungkinkan untuk mengekstrak secara keseluruhan kandungan total lipida makroalga basah. Makroalga dalam pelaksanaan ektraksi lebih mudah untuk diekstraksi karena sel-sel pengotor lebih sedikit dibandingkan dengan penanaman pada limbah cair atau limbah artificial lainnya. Selain itu, penggunaan makaroalga basah lebih efisien untuk diterapkan dimasa depan karena tidak memerlukan penggunaan energi untuk pengeringan.

\subsection{Analisa asam lemak makroalga}

Tabel 2. menunjukkan hasil identifikasi senyawa minyak/lemak menggunakan alat GC dengan hasil grafik 5 puncak. Tiga puncak tertinggi diketahui mengandung senyawa 9-Octadecanoic acid (Z), methyl ester (Asam oleat) sebesar $52.44 \%$ area, 9-12,Octadecadienic, (Z.Z) methyl ester (Asam linoleat) sebesar $22.12 \%$ area dan Octadecanoic acid, (CAS) methyl stearate, sebesar $20.36 \%$ area.

Pada kajian yang dilakukan oleh Knothe (2005) disebutkan berat molekul metil oleat (asam oleat) yang dihasilkan adalah sebesar $282.468 \mathrm{gram} / \mathrm{mol}$ yang berkorelasi dengan salah satu asam lemak yang berpotensi sebagai salah satu bahan baku biodiesel berdasarkan sifat fisik asam lemak yang dihasilkan. Ketiga asam lemak ini merupakan komponen utama yang umumnya terdapat didalam minyak alga dan berpotensi untuk dimanfaatkan sebagai bahan baku biodiesel. Selain itu juga dapat diketahui bahwa asam oleat termasuk salah satu senyawa lemak yang berperan cukup penting dalam pembentukan asamasam lemak bebas makroalga, dikarenakan prosentase methyl oleat (asam oleat) yang cukup tinggi (52.44\%) dibandingkan senyawa asam lemak lainnya.

Asam lemak jenuh tidak memiliki ikatan yang solid, sedangkan asam oleat merupakan asam lemak tidak jenuh yang memiliki satu ikatan yang kuat (juga digambarkan sebagai olefin). Asam lemak tak jenuh ganda seperti asam linolenat mengandung dua atau lebih ikatan padat. Asam laurat (juga disebut asam dodecanoic) adalah asam utama dalam minyak kelapa (45-50\%) dan minyak sawit (45-55\%) (http:chemicalland21.com).

Hasil identifikasi profil asam lemak menunjukkan bahwa proses ektraksi satu tahap menghasilkan kandungan asam lemak yang tinggi dengan kandungan asam oleat sebesar $52.44 \%$ area dengan berat molekul rata-rata asam lemak yang dihasilkan dari ekstraksi satu tahap makroalga basah adalah 282.77 gram/ mol (Tabel 2), dan berada dalam range berat molekul asam lemak metil ester. Dengan ini dapat disimpulkan bahwa proses ektraksi satu tahap pada makroalga basah berpotensi dan dapat diterapkan dimasa yang akan datang untuk memproduksi bahan baku biodiesel skala besar dari makroalga, terutama makroalga dalam bentuk basah dengan kandungan air tinggi.

\section{Kesimpulan}

Proses ekstraksi satu tahap berpotensi untuk digunakan sebagai salah satu metode untuk ekstraksi lipida makroalga baik dalam bentuk basah maupun kering. Terbukti dari profil asam lemak yang dihasilkan yaitu Asam oleat sebesar 52.44\% area, Asam linoleat sebesar $22.12 \%$ area dan Octadecanoic acid, (CAS) methyl stearate, sebesar $20.36 \%$ area. Ketiga asam lemak ini berpotensi sebagai bahan baku biodiesel.

\section{Ucapan Terimakasih}

Ucapan terima kasih kami yang sebesarnya kepada mahasiswa dan laboran Teknik Lingkungan yang telah banyak membantu dalam pengambilan sampel makroalga dan karakterisasi makroalga perairan lokal Aceh.

\section{Daftar Pustaka}

AOAC, 2005, Official method of Analysis. 18th Edition, Association of Officiating Analytical Chemists, Washington DC

Ariyanti, D. dan Handayani N. A. 2012. Mikroalga Sebagai Sumber Biomassa Terbarukan : Teknik Kultivasi dan Pemanenan. Skripsi. Fakultas Teknik Kimia. Universitas Dipenegoro. Semarang.

Axelsson, M. 2014. A Single-Step Method for Rapid Extraction of Total Lipids from Green Microalgae. Plos One. 9

Bligh, E.G.; Dyer, W.J. 1959. A rapid method of total lipid extraction and purification. Can. J. Biochem. Physiol. 37, 913-917.

Dawes, J. 1998. Marine Botany. University of Florida. Florida.

Fishwick. M.J, Wright A.J (1977) Comparison of methods for the extraction of plant lipids. Phytochemistry 16: 1507-1510.

Folch, J. M. Less, G.H.S Stanley, 1957. A simple method for the isolation and purification of total lipids from animal tissues. J. Biol. Chem., 226.

Knothe, G. 2005. Dependence of biodiesel fuel properties on the structure of fatty acid alkyl esthers, Fuel Processing Technology. 86. 10591070 .

Narsi. 2007. Oilgae Guide to Fuels from Macroalgae. A Report by Oilgae. Tamilnadu. India. 
Nugroho, A. 2010. Rumput Laut. Laboratorium Budidaya Perairan. Fakultas Perikanan dan Ilmu Kelautan. Universitas Diponegoro. Semarang.

Prommuak, C. Pasavati, P. Quintain, A.T. Goto, M. Shotipruk, A. 2012. Microalgal Lipid Extraction and Evaluation of Single-Step Biodiesel Production. Engineering Journal. Vol 16 Issue 5.

Susanto, E., 2012. Pembuatan Biodiesel Dari Alga Nannochloropsis $s p$ dalam Prosiding Seminar Nasional Teknik Kimia Soebardjo
Brotohardjono Ix. Jawa Timur: Program Studi Teknik Kimia UPN Veteran.

Winarno, F.G. 1990. Teknologi Pengolahan Rumput Laut. Pustaka Sinar Harapan.Jakarta.

Yang, F., Xiang W., Sun X., Wu H., Li T., and Long, L. 2014. A Novel Lipid Extraction Method from Wet Microalga Picochlorum sp. at Room Temperature. Marine drugs. 12. 1258-1270

http://www.bphmigas.go.id/konsumsi-bbm-nasional [diunduh 9 Januari 2019].

http://chemicalland21.com/index.html [diunduh 18 Januari 2019] 